\title{
Spatio-statistical comparative approaches for landslide susceptibility modeling: case of Mae Phun, Uttaradit Province, Thailand
}

\author{
Muhammad Farhan UI Moazzam ${ }^{1}$ [ . Anujit Vansarochana ${ }^{1}$. Jaruntorn Boonyanuphap ${ }^{1} \cdot$ Sittichai Choosumrong ${ }^{1}$. \\ Ghani Rahman ${ }^{2} \cdot$ Geraud Poueme Djueyep ${ }^{3}$
}

Received: 24 November 2019 / Accepted: 23 January 2020 / Published online: 12 February 2020

(c) Springer Nature Switzerland AG 2020

\begin{abstract}
In this study for landslide susceptibility modeling, three quantitative techniques, i.e., frequency ratio (FR), information value (IFV), and weight of evidence (WOE), were evaluated and compared. For this purpose, landslide inventory map was prepared using visual interpretation on SPOT-5 image and field survey was carried out for ground truthing of landslide sites and total 677 landslides were identified. The inventory map was divided into training and validation datasets, and from total, 473 landslides (70\%) were for training to run the model and 30\% (204 landslides) for validation purpose. Total 11 landslide conditioning factors were used in this study that are: elevation, slope, aspect, curvature, plan curvature, profile curvature, land use/land cover (LULC), topographic wetness index (TWI), stream power index (SPI), proximity to road, and proximity to stream. Three different landslide susceptibility maps were produced based on analyzing the relationship of landslides with conditioning factors using FR, IFV, and WOE in GIS environment. The results of FR model indicated that almost $40 \%$ of the total study area fall in high to very high landslide susceptibility zones, while in WOE and IFV models, it was found almost $50 \%$ of the total area. The landslide susceptibility maps were validated using prediction and success rate curve techniques. The prediction rate curve gives us a glimpse of future landslides based on present landslide susceptibility maps. The results obtained from validation showed that the area under curve (AUC) based on prediction rate curve for FR, IFV, and WOE was $80.78 \%, 72.88 \%$, and $72.33 \%$, respectively. However, the AUC obtained through success rate curve for the models in this study was $74.60 \%, 75.04 \%$, and $72.54 \%$ for FR, IFV, and WOE, respectively. Moreover, the evaluation of landslide density test and seed cell index area (SCAI) indicated that calculated and classified landslide susceptibility maps are in a good agreement with the field conditions. Thus, it was observed from this study that the frequency ratio has better accuracy as compared to information value and weight of evidence, but in success rate curve, almost all the models showed the same results. Consequently, it can be concluded that the susceptibility maps produced from FR, IFV, and WOE are in good agreement because more than two-third of landslides falls in high and very high susceptibility zones of each model. From this study, it was found that slope angle, elevation, land use/ land cover, and roads play a major influencing role in the occurrence of landslide in the study area. The maps produced based on these landslide susceptibility models provide a base for engineers and land use planner to develop landslide management strategies before any development on slopes.
\end{abstract}

Keywords Frequency ratio $\cdot$ Information value $\cdot$ Weight of evidence $\cdot$ Landslide susceptibility $\cdot$ Prediction rate curve

$\triangle$ Muhammad Farhan UI Moazzam, farhan.moazzam@gmail.com; Anujit Vansarochana, anujitv@nu.ac.th; Jaruntorn Boonyanuphap, charuntornb@nu.ac.th; Sittichai Choosumrong, sittichaic@nu.ac.th; Ghani Rahman, ghani_geo@yahoo.com; Geraud Poueme Djueyep, pouemegeraud@gmail.com | 'Department of Natural Resources and Environment, Faculty of Agriculture, Naresuan University, Phitsanulok, Thailand. ${ }^{2}$ Department of Geography, University of Gujrat, Gujrat, Pakistan. ${ }^{3}$ Department of Earth Sciences, Sapienza University of Rome, Rome, Italy. 


\section{Introduction}

Landslides were found to be the most frequent and damaging natural hazard threatening human lives and properties [1]. Landslide is the devastating natural hazard causing serious human injuries, loss of lives, and heavy property damages every year in the mountainous region around the globe $[2,3]$. The major triggering factors of landslides include earthquake, rainfall, storms, mining activities, and deforestation [4-6]. Every year thousands of people lost their lives, and about 4 billion dollars property damage occurs globally due to landslide $[7,8]$. It is the third most devastating natural hazard in terms of damages after earthquake and flood [9]; however, individual landslide is not so obvious and devastating as an event of earthquake and flood [10]. Identification of the factors responsible for existing landslides is the initial step toward the prediction of future landslides by analyzing the most influencing factors, and the processes are known as landslide susceptibility mapping studied by various researchers around the globe [11]. Landslide is a natural phenomenon that cannot be completely stopped, but its associated risk can be minimized. Landslide susceptibility modeling identifies the vulnerable areas and its relationship with various influencing factors. Globally, it is a widely studied phenomenon and various quantitative and qualitative methods have been developed for landslide susceptibility modeling $[10,12]$. The qualitative method helps to rank the conditioning factors based on the precedence scale, whereas the quantitative methods highly depend upon the relationship between conditioning factors and landslide inventory to classify the area into different landslide susceptible zones [13]. The researchers have used various models for landslide susceptibility mapping, i.e., analytical hierarchy process $[14,15]$, frequency ratio $[8$, $16,17]$, information value $[18,19]$, weight of evidence $[20,21]$, and many other machine learning methods for landslide susceptibility assessment. In this study, three models IFV, WOE, and FR have been used as these three models are widely used in landslide studies across the globe and have been found most significant in landslide assessment in different mountainous regions of the world. The geographical information technology like GIS and remote sensing is widely used in the current century for such location-based issues like landslide hazard assessment [22]. In the past two decades, there has been an incredible transformation occurred in these technologies [23]. DEM is processed in GIS environment for the extraction of various thematic layers contributing toward the hazard assessment, i.e., elevation, slope,

\section{SN Applied Sciences}

aspect, curvature, topographic wetness index, and stream power index [24].

In the study area, rainfall and landslides have a direct relationship [25-27] and that is why in May 2006, heavy rainfall triggered a devastating landslide in Mae Phun, Thailand $[28,29]$, that caused 17 human losses and damaged 169 houses [29]. The main aim of this study is to compare three bivariate quantitative models, i.e., frequency ratio, information value, and weight of evidence model, and to suggest the most significant model for landslide susceptibility mapping in the study area.

Many studies have been conducted on landslides assessment and its effects in different parts of Thailand [30-34], although there is no such detailed study conducted on landslide for the given study area as well as in those studied they did not used that much detailed influencing factors for landslide modeling, which make this research different from the previous ones. For landslide prediction, it is assumed that the conditioning factors that caused landslide in past are responsible for initiation of landslide in future $[7,10]$.

\section{Materials and methods}

\subsection{Study area}

The study area is Mae Phun a sub-district of Laplae District, Uttaradit Province, that covers an area of 131 square kilometers. Elevation of the area varies from 100 to $853 \mathrm{~m}$ above mean sea level (Fig. 1). Slope gradient in the study area ranges from $0^{\circ}$ to $69^{\circ}$. The area is located near the upstream of Nan river basin [28]. Most of the study area is covered with hillside and steep, narrow plain in valley groove [35] The study area has tropical savanna type of climate, mean annual rainfall is $1506 \mathrm{~mm}$, and mean annual humidity is $73 \%$ (1971-2010). In the months of May to October, monsoon brings heavy rainfall. Winter is dry and warm with an average maximum daily temperature $38.2^{\circ}$ centigrade, and it rises in the month of April. The lithology of the study area consists of shale and siltstone in mountainous regions; however, alluvial deposits are present in the southern plain areas. Soil texture in the study area consists of mudstone, shale, and chest [28,35]. Land cover in the study area consists of residential area, rural community, lowland paddy field, mountainous mixed deciduous upstream forest, and mixed fruit tree orchard in lowland areas [28].

\subsection{Methodology}

Landslide susceptibility analysis has four major steps: (1) collection and integration of data in spatial database, (2) 
Fig. 1 Location map of the study area and landslide inventory

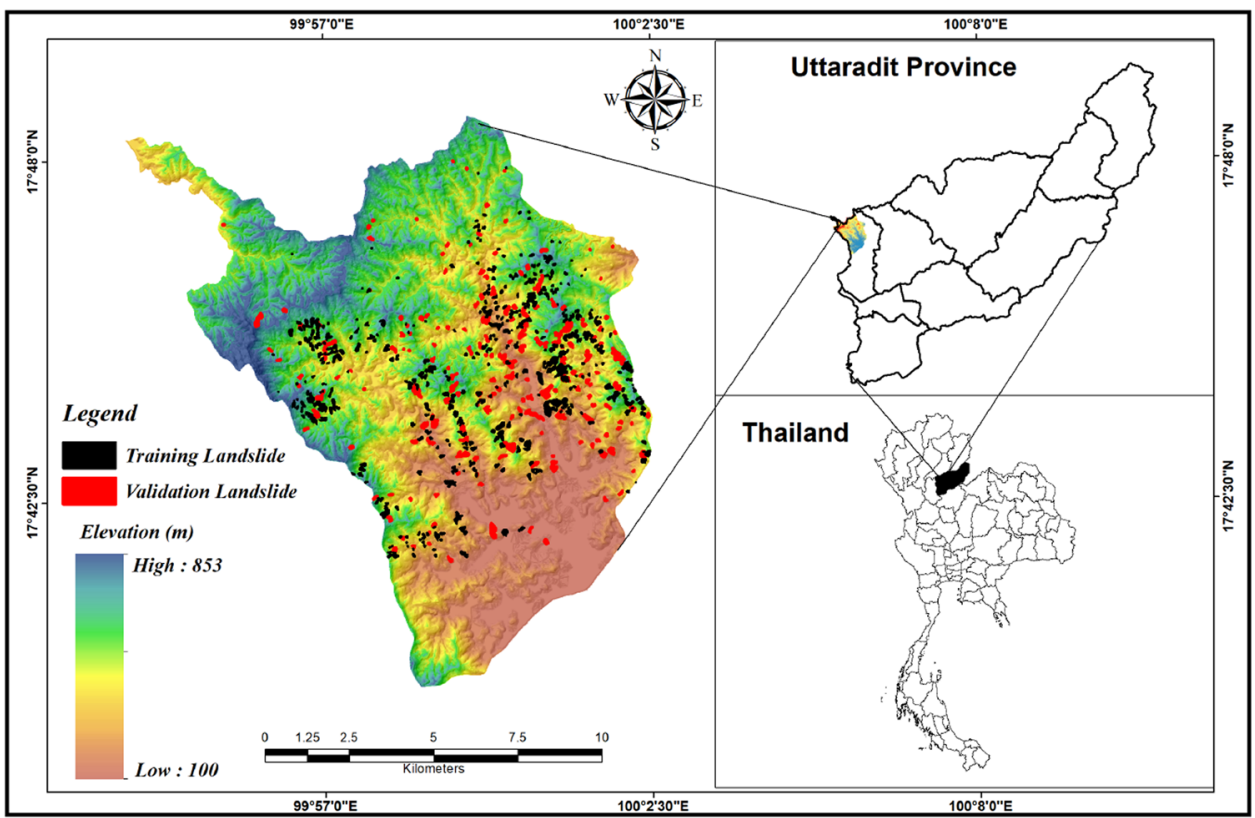

landslide susceptibility assessment using relationship of conditioning factors and landslide inventory, (3) validation of the results, and (4) comparison and interpretation of the results [36]. Figure 2 shows the detailed road map of this study.

\subsection{Landslide inventory map}

Mapping of past landslide area is an essential part of landslide susceptibility mapping [37]. In landslide inventory mapping, the information on past landslides location, type, time, depth of the landslides, etc., is collected [38]. Locations of past landslide were mapped

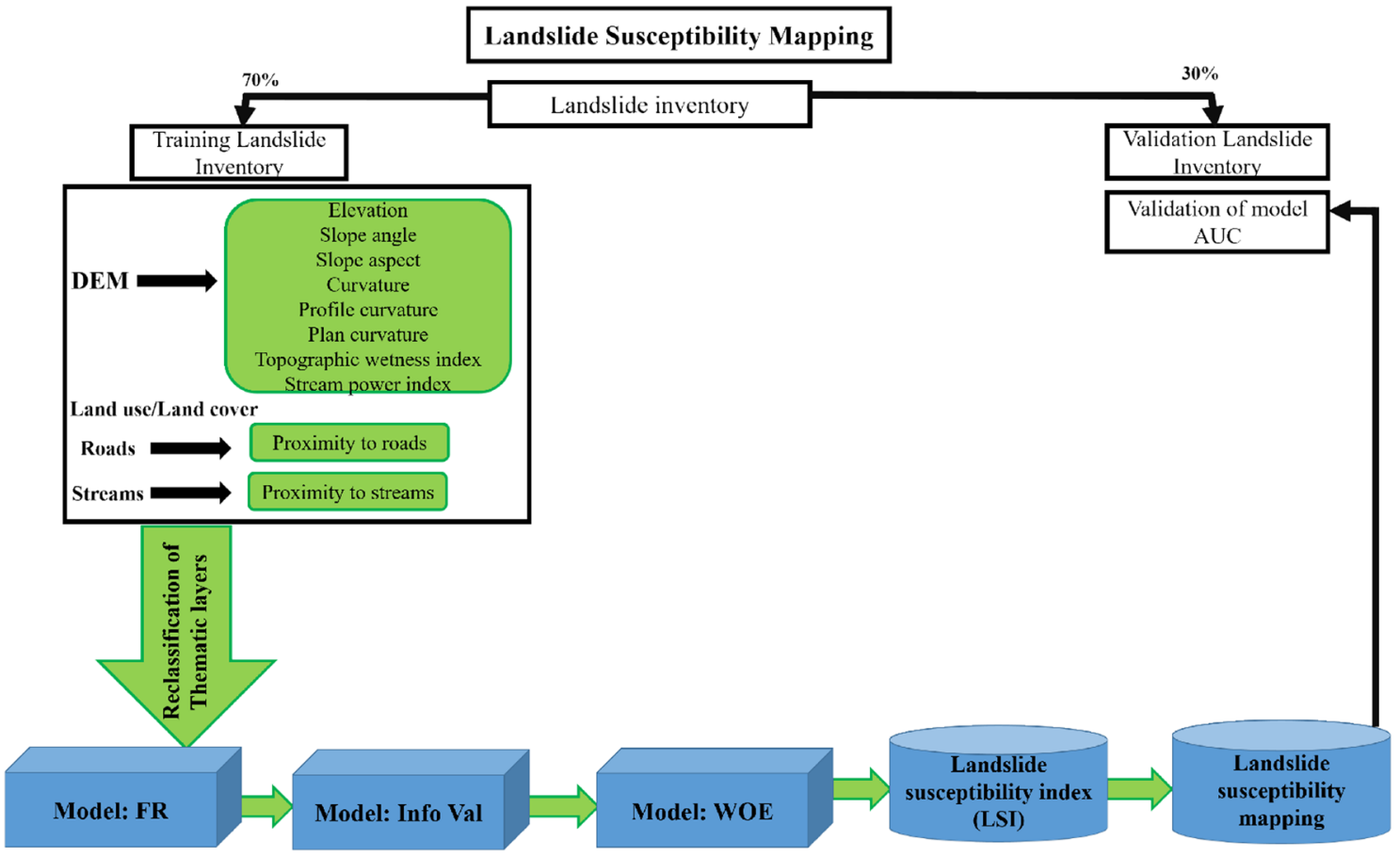

Fig. 2 Flowchart of research 
on SPOT-5 image and then validated with field visits eventually, and 677 landslide locations were identified. Landslide inventory was drawn as a polygon layer in ArcGIS and then rasterized with $5 \mathrm{~m} \times 5 \mathrm{~m}$ spatial resolution. Identified landslides cover an area of $4.25 \mathrm{~km}^{2}$, which accounts $3.24 \%$ of the total study area. Landslide inventory data were randomly split into training and validation landslides as it is widely used percentages in the literature [39]; out of total, 473 (70\%) were selected as training landslides (with an area of $2.68 \mathrm{~km}^{2}$ accounting $2.04 \%$ of the total study area) to construct landslide susceptibility map, and the remaining 204 (30\%) were used for validation of the applied models.

\subsection{Landslide influencing parameters}

Accuracy of the susceptibility map depends on the selection of the conditioning factors and assessment methodology [37, 40]. Although no specific guideline exists for the selection of the landslide conditioning factors [41], its selection depends on the nature of the study area and availability of data [42]. For this research, a thorough field study was carried out on the basis of field investigations, and literature reviewed helped to choose these 11 conditioning factors, i.e., elevation, slope, slope aspect, curvature, profile curvature, plan curvature, stream power index (SPI), topographic wetness index (TWI), land use/land cover, proximity to streams, and proximity to roads. Study area is affected by rainfall-triggered landslide that is why rainfall is considered as a triggering factor.

\subsubsection{Land use/land cover}

Many studies have shown strong relationship of land use with the occurrence of landslide [43-45], as barren land contributes more to landslide occurrence as compared to vegetative areas. The vegetative land reduces the impact of climate, and the roots bound the soil [18]. Deforestation, agricultural activities on slope, and construction of road network mostly disturb the slope stability and make it more susceptible to landslides [8, 46]. Clear-cutting of coppice for agricultural, buildings, or road development increases the risk of both landslides and floods [47]. Land use/land cover data were acquired from Land Development Department, Bangkok (Fig. 3).

\subsubsection{Proximity to streams}

It is a significant parameter for slope stability studies, and it can adversely affect the slope by vertical and lateral erosion and thus reduce the shear resistance $[48,49]$.

\subsubsection{Proximity to roads}

Roads are human-induced parameter which can cause landslide [41]. Extensive digging, extraneous loads, and deforestation are mostly observed near the road network, and all these support slope failure [1].

\subsubsection{Rainfall}

Rainfall is an extrinsic variable widely used in susceptibility analysis, and its spatial distribution of annual rainfall
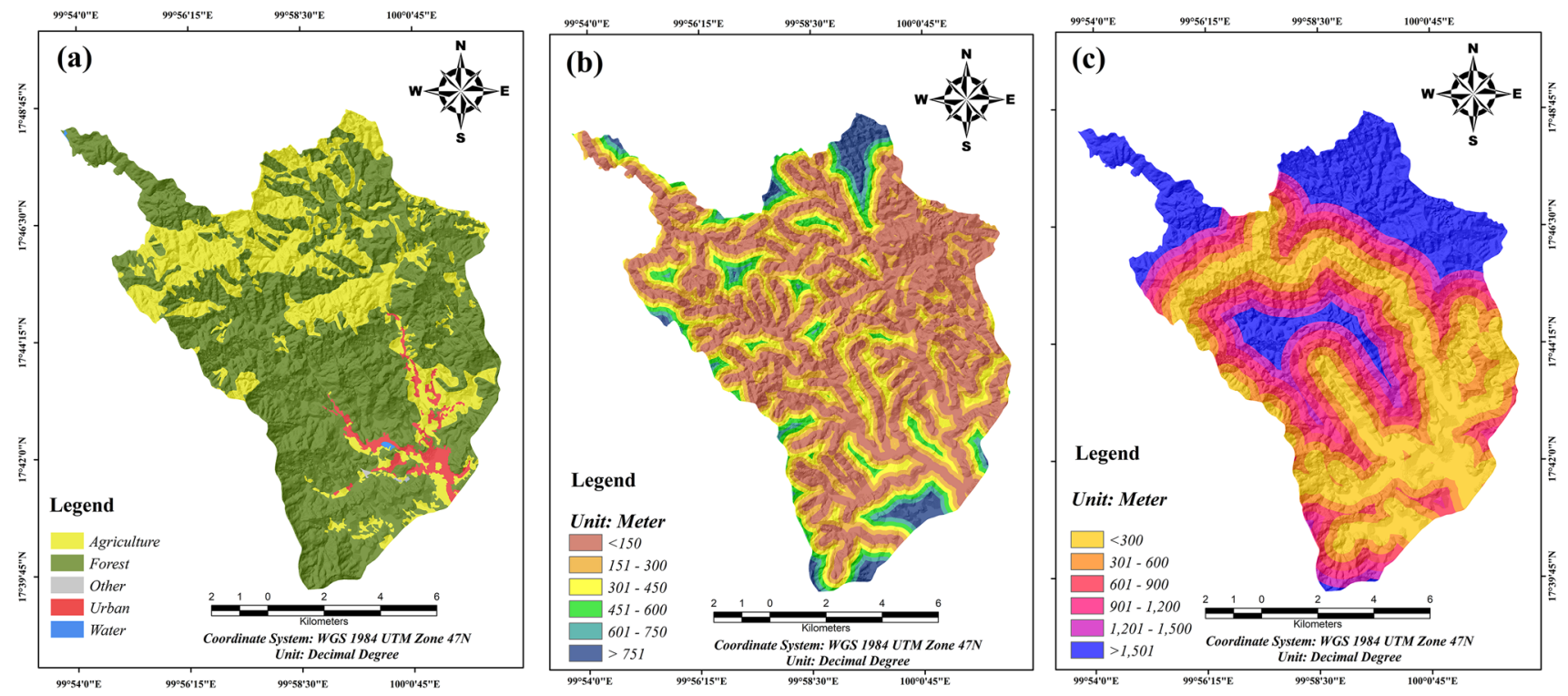

Fig. 3 a Land use/land cover, b proximity to streams, c proximity to roads 
is commonly considered in statistical hazard analysis [50, 51]. In study area, landslide was triggered by heavy rainfall. Therefore, annual rainfall data of eight stations around the study area were used to prepare rainfall intensity map. Rainfall data were obtained from Thai Meteorological Department, Thailand. Rainfall intensity map was obtained by applying IDW technique (Fig. 4i). About $50 \%$ study area was dominated by two rainfall classes, i.e., 995.9-1037.8 and $1037.9-1068.6 \mathrm{~mm} /$ year.

\subsubsection{DEM-derived conditioning factors}

Digital elevation model data of the study area were downloaded from (Advanced Space borne Thermal Emission and Reflection Radiometer). All topographical parameters, i.e., elevation, slope gradient, slope aspect, slope curvature, plan and profile curvature, TWI, and SPI were extracted from DEM.

\subsubsection{Elevation}

It is considered as one of the important contributing factors in landslide occurrence $[41,52,53]$. It is an evident fact that the temperature decreases with elevation, while rainfall increases with increase in elevation. The high amount of rainfall on fragile slopes leads to landslide occurrence [44].

\subsubsection{Slope gradient}

It is another most widely used conditioning factor in landslide studies [3, 19, 41, 44], as it has a direct relationship with the occurrence of landsliding.

\subsubsection{Slope aspect}

It has relation with sunlight exposure, winds, soil moisture content on a slope, and these factors indirectly cause landslide occurrence $[3,10]$.

\subsubsection{Slope curvature}

It is an important geomorphic index of topographic feature, defined as the rate of change of slope in certain direction. It adversely affects the surface erosion by converging and diverging the runoff down the slope [54-56]. It has two utmost values: Positive values indicate the surface is convex in upward direction at certain location, while negative values specify that surface is concave in upward direction. Higher the negative value increase, the more the probability of landslide occurrence; on the contrary, comparatively flat area is less exposed to landslide. Slope with concave surface will tend to hold more rainfall water; thus, it has more time for water infiltration into slope and thus increases the probability of landslide occurrence, but the case is opposite for convex slope [55].

The combination of plan and profile curvature along with curvature is taken into consideration so that slope morphology and flow can be better assessed.

\subsubsection{Stream power index}

SPI measures the erosive power of stream, and it is considered as a significant contributing factor that can control the slope stability in the certain area [57]. Higher SPI values indicate steep, straight, scoured reaches, and bedrocks; however, lower values represent broad alluvial flats, floodplains, and slowly subsiding areas, where the valley fill is mostly intact and deepening [58].

$\mathrm{SPI}=\mathrm{As} \times \tan \beta$

where "As" is the catchment area and $\beta$ is the slope gradient in degrees.

\subsubsection{Topographic wetness index}

TWI is used to quantify the topographic control on hydrological process. TWI can measure the degree of accumulation of water at a site. TWI and landslide have a direct relationship if the value of TWI increases the occurrence of landslide [59]. TWI was extracted from DEM, and the formula is given below.

$\mathrm{TWI}=\ln (\mathrm{As} / \tan \beta)$

where "As" is the catchment area and $\beta$ is the slope angle in degrees.

\subsection{Frequency ratio model (FR)}

FR is a bivariate geo-statistical method to compute the probabilistic correlation between independent and dependent variables [60]. For landslide prediction, it is assumed that the conditioning factors that caused landslide in past may be responsible for initiation landslide in future $[7,10]$. The main advantage of FR model is that it is very easy to use and obtain the results that are readily intelligible [1].

FR is based on the correlation of landslides and its conditioning factors. FR is the ratio of the landslides to the total study area; in addition, it is also the ratio of landslide and non-landslide area for a given attribute/class of a parameter. Therefore, calculating FR values, the area ratio with landslide to non-landslide was computed for each class of each factor for the whole study area, and then, area ratio of each class of each factor to the whole study 

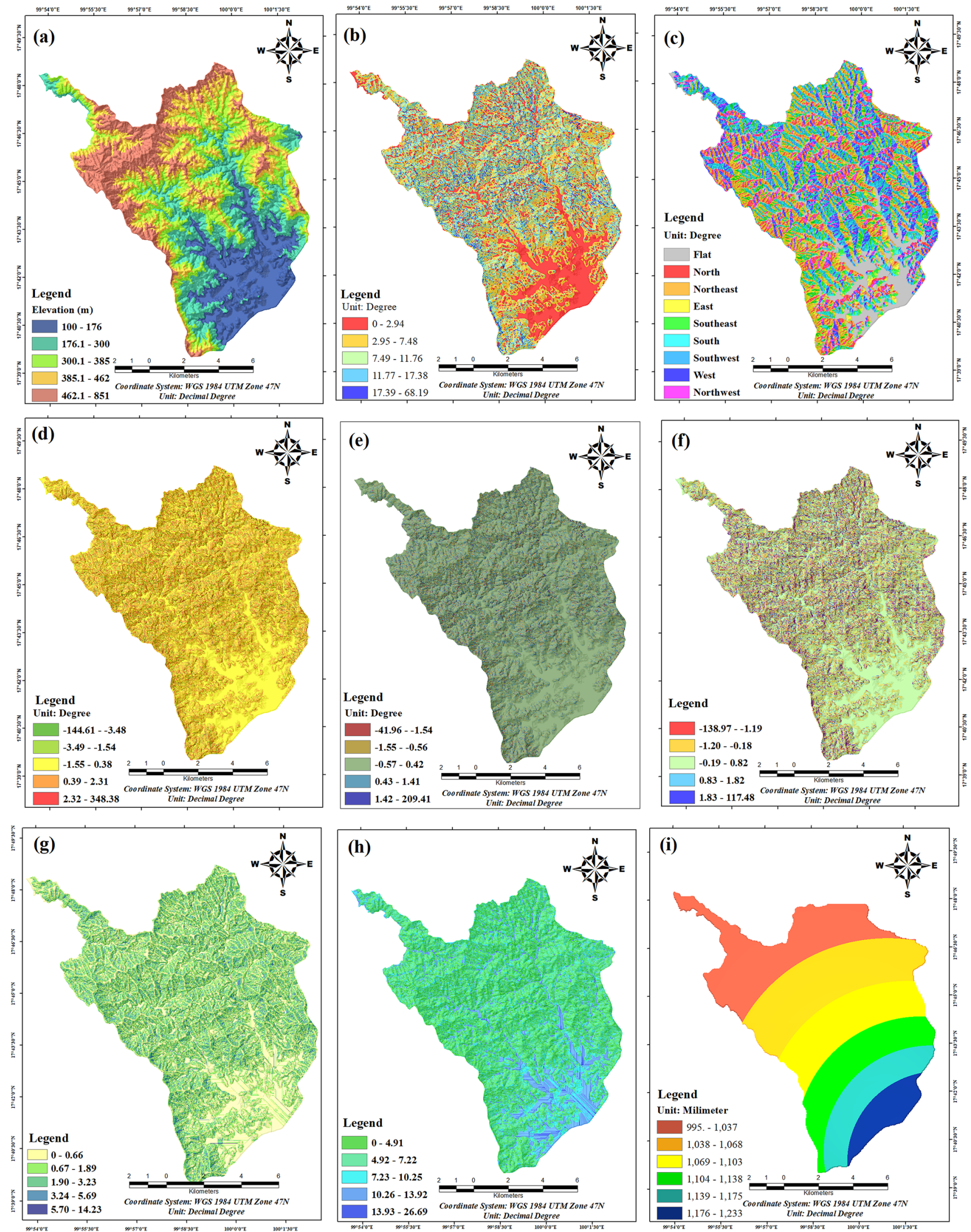

Fig. 4 a Elevation, b slope gradient, $\mathbf{c}$ slope aspect, $\mathbf{d}$ slope curvature, e plan curvature, $\mathbf{f}$ profile curvature, $\mathbf{g}$ stream power index, $\mathbf{h}$ topographic wetness index, i) rainfall intensity 
area was calculated. Hence, FR value of each class type was obtained by dividing the ratio of landslide to the ratio of study area $[1,7,21]$.

$\mathrm{FR}=\frac{N_{\text {pix (Li) }} / N_{\text {pix (Ci) }}}{\sum N_{\text {pix }(\mathrm{Li})} / \sum N_{\text {pix(Ci) }}}$

where $N_{\text {pix(Li) }}$ is the landslide pixels in class $\mathrm{i}$, whereas $N_{\text {pix (Ci) }}$ is the number of pixels in class $\mathrm{i}, \sum N_{\text {pix (Li) }}$ is the total number of landslide pixels, and $\sum N_{\text {pix(Ci) }}$ is the total number of pixels in the study area.

To produce landslide susceptibility index (LSI), FR values of all the factors were summed up using Eq. 2. LSI map was classified into various classes based on landslide susceptibility.

$\mathrm{LSI}=\sum(\mathrm{Fr} 1+\mathrm{Fr} 2+\mathrm{Fr} 3 \ldots \mathrm{Frn})$

where LSI is the landslide susceptibility index; " $\mathrm{Fr}$ " is frequency ratio value of each conditioning factor, and " $n$ " is the total number of factors used. The FR value of 1 (one) is normal; if the FR value is superior than 1 (one), it means that the factor has high correlation with landslide and vice versa $[1,44]$.

\subsection{Information value method (IFV)}

The information value model was first developed by Yin and Yan [61] and later on modified by Van Westen [62]. This model is based on Bayesian algorithm [63]. It is a useful approach for landslide susceptibility mapping by determining the impact of parameters on landslide occurrence in the study area [64]. It can be used to estimate the information value for each class of a parameter by dividing the landslide density in each class to the total landslide density in the target area [62]. The main aim of the natural logarithm is to take into the consideration of large variation in the information values, and if the landslide density is lower than normal, it gives negative weights; on the contrary, it gives positive weights when the density of landslide is higher than average [65].

$\mathrm{IFV}=\ln \left(\frac{\text { Densclass }}{\text { Densmap }}\right)=\ln \frac{N_{\text {pix(Li) }} / N_{\text {pix(Ci) }}}{\sum_{i=1}^{n} N_{\text {pix (L) }} / N_{\text {pix(C) }}}$

where IFV is the information value of each conditioning factor. Positive values of Li specify the relevant correlation of landslide incidence and its related conditioning factor; the higher the score is, the more stronger will be the relationship, and negative value indicates the inverse correlation of landslide and certain inducing factors [61]. Using Eq. 5, weight values for each class of the influencing parameter were calculated and landslide susceptibility index (LSI) was prepared by summing up all the weight values of each factor using Eq. 4.

$\mathrm{LSI}=\sum_{i=1}^{n} \mathrm{IFV}$

where $\mathrm{n}$ is the number of influencing factors used, and IFV is the information value of each conditioning factor.

\subsection{Weight of evidence (WOE)}

WOE uses Naïve Bayesian approach to estimate the comparative significance by means of statistical values [32]. Initially, this method was used for identification of minerals [66] and later on used for landslide susceptibility assessment by many researchers [21, 50, 51].

Detailed mathematical formulation of WOE approach is given in [66], and weights of each landslide conditioning factor were calculated on the basis of the absence or presence of landslide in each class of conditioning factor.

$P\left(\frac{A}{B}\right)=P\left(\frac{\left(\frac{B}{A}\right) \times P(A)}{P(B)}\right) \frac{P(A)}{P(B)}$

In this approach, weights were computed for all the influencing parameters $(B)$ and its relationship with the absence or presence of landslide $(A)$ within the study area [66].

$W+=\log \left[\frac{P\{B / A\}}{P\left\{B / A^{-}\right\}}\right]$

$W-=\log \left[\frac{P\left\{B^{-} / A\right\}}{P\left\{B^{-} / A^{-}\right\}}\right]$

where $P$ is the probability, log is the natural logarithm, $B$ is the presence of desired class of landslide conditioning factor, $\bar{B}$ is the absence of desired class of landslide conditioning factor, and $A$ is the presence and $\bar{A}$ is the absence of landslides. Positive $(W+)$ indicates the positive relationship between the presence of landslide and given class of a conditioning factor and vice versa. Eventually, the difference between two weights is calculated using Eq. 10 which is known as the contrast weight. Based on contrast values, the spatial correlation of landslide and its influencing parameters can be described $[21,66]$.

$W+=\log \left[\left(\mathrm{LS}_{\text {in }} \%\right) /\left(\right.\right.$ nonLS $\left._{\text {in }} \%\right)$

$W-=\log \left[\left(\mathrm{LS}_{\text {out }} \%\right) /\left(\right.\right.$ nonLS $\left._{\text {out }} \%\right)$

where $\left(\mathrm{LS}_{\text {in }} \%\right)$ and $\left(\right.$ nonLS $\mathrm{Sin}_{\mathrm{in}} \%$ ) are the percentages of the presence and absence of landslide pixels in the given class 
of a parameter, respectively, and $\left(\mathrm{LS}_{\text {out }} \%\right)$ and $\left(\right.$ non $\left.L S_{\text {out }} \%\right)$ are the percentages of landslide and non-landslide pixels out of the desired class.

$W^{c}=W^{+}-\left(W^{-}\right)$

Value of ' $C$ ' ranges from 0 to 2, whenever the value of ' $C$ ' tends to zero in any parameter, meaning that it does not have any impact on the distribution of landslide in the area; on the other hand, if the value is 2 or more, the relationship between the parameter and landslide is very strong.

\section{Results and discussion}

The landslide susceptibility maps were produced with three bivariate quantitative statistical models using GISbased approach and compared with each other.

\subsection{Frequency ratio and landslide susceptibility}

The resultant FR values of each thematic layer are given in Fig. 5. The slope aspect results show that the northeast-, east-, southeast-, south-, and south-facing slopes have greater than 1 (one) frequency ratio value indicating high probability of landslide incidence in these classes of aspect map. Analyzing the relation of landslides with elevation, it was found that in the classes ranging from 177 to 462 meters, the value of frequency ratio is higher than 1 (one) and the other classes have less than one FR value. All the classes in degree slope map show strong relationship with land sliding as the value of $F R$ is higher than one in all the classes except $0^{\circ}-2.94^{\circ}$ class. FR values for land use/land cover are higher only in the class of forest cover $(F R=1.20)$. The relationship between landslide and roads shows that the FR value ranges from 1.40 to 1.58 in $600-1500 \mathrm{~m}$ proximity to roads. The FR values for the relationship between streams and landslide are higher than 1 at the buffer classes, ranging from 151 to $450 \mathrm{~m}$ from the

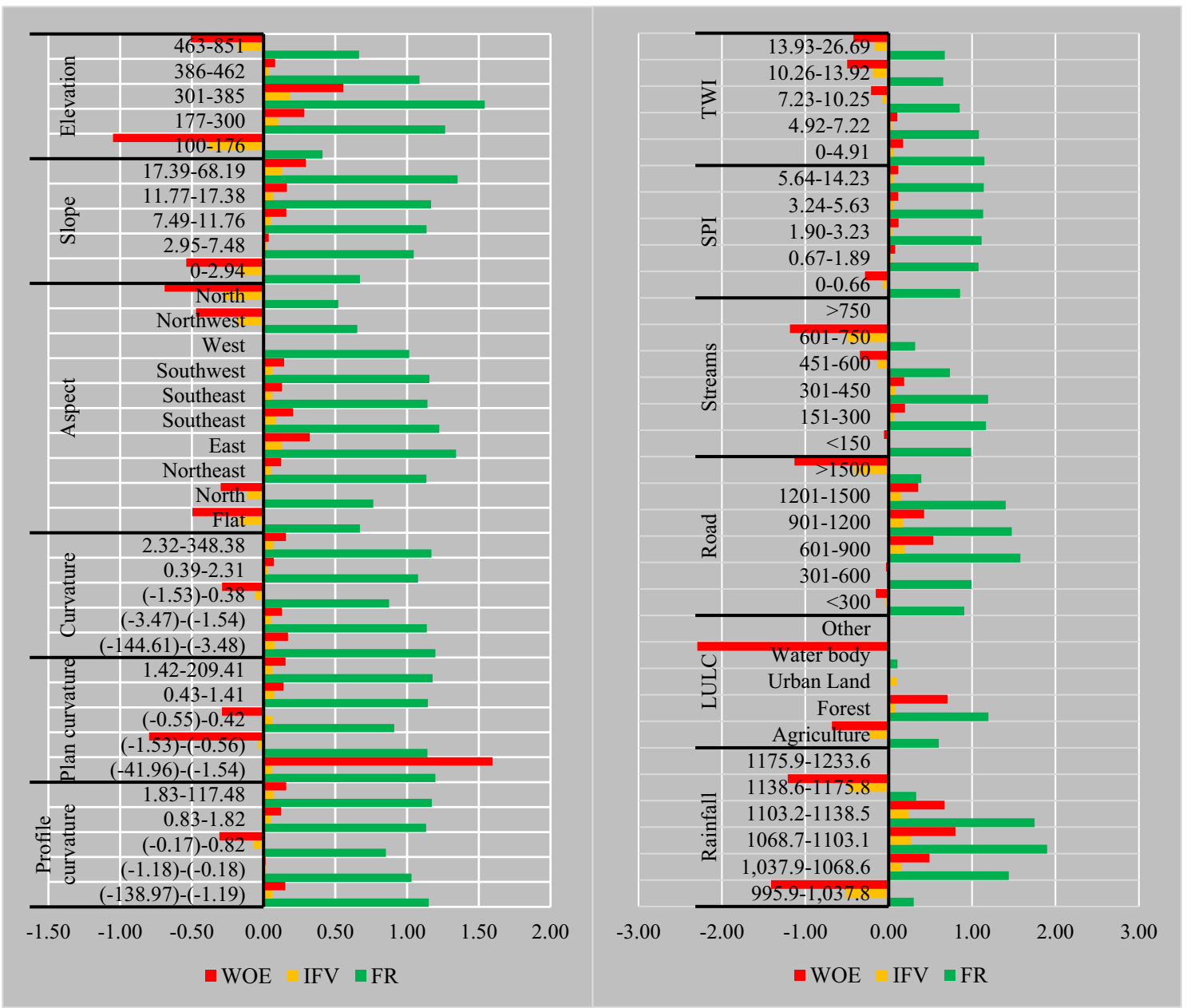

Fig. 5 Data used in the analysis and results obtained from frequency ratio, weight of evidence, and information value methods 
streams. FR values were high for the TWI classes 0-4.91 and 4.92-7.22. The values of FR for SPI were 1.11-1.14 for the classes $1.90-3.23,3.24-5.63$, and 5.64-14.23, respectively. Curvature values indicate the morphology of the topography; positive values show upward convex, and on the contrary, negative values are showing upwardly concave surfaces. In curvature, both the concave area and convex area have higher FR values (1.03-1.20) that indicate higher possibility of landslide occurrence for all types of curvature. Resultant LSI map was reclassified into five various susceptibility zones ranging from very high to very low, classified with natural break method (Fig. 6a).

\subsection{Information value and landslide susceptibility}

To analyze the role of each class of a particular conditional parameter, the information value method was applied and the resultant weight was calculated (Fig. 5). Land use/land cover maps show that three-fourth of landslides occurred in the classes of forest and urban land having information value of 0.078 and 0.097 , respectively, and agriculture land has lowest impact on landslide incidence (-0.222 information value). Slope is a significant and most widely used influencing factor and has been used by many researchers in landslide studies. It has a direct relationship with landslide, and analyzing the slope and landslide occurrence, the result shows that high landslide occurrence ranges from $2.95^{\circ}$ to $68.19^{\circ}$ slope classes, while the information value was minimum $(-0.173)$ for the class of $0^{\circ}-2.94^{\circ}$ slope. The result of information values for elevation and aspect ranges from -0.387 to 0.188 and -0.173 to 0.128 , respectively, with approximately $79 \%$ of landslide area in the range of $177 \mathrm{~m}-462 \mathrm{~m}$ of elevation classes, and around $77 \%$ of landslide area is in the categories of NE-, $\mathrm{E}-, \mathrm{SE}-, \mathrm{S}-, \mathrm{SW}-$, and $\mathrm{W}$-facing slopes of aspect parameter. As for TWI parameter, two-third of (76.52\%) of the landslide incidences was found within the classes of 0-4.91 and 4.92-7.22, respectively. The concave and convex slope categories of curvature, profile, and plan curvature parameters have the highest information value, and the landslide area occupied by these categories is $56.54 \%, 61.74 \%$, and $42.30 \%$, respectively. As for distance from roads, highest information values were found within $600-1500 \mathrm{~m}$ around the road with information values ranging from 0.147 to 0.198 . Distance from streams gives highest information value of 0.076 for the distance between 300 and $600 \mathrm{~m}$ followed by the class of $150-300 \mathrm{~m}$ with information value of 0.067 .

LSI obtained from information value method was divided into five susceptibility zones and is shown in Fig. 6b.

\subsection{Weight of evidence and landslide susceptibility}

The positive and negative weights along with contrast values for each class of conditioning parameters are given in Fig. 5. The elevation class below $176 \mathrm{~m}$ and above $462 \mathrm{~m}$
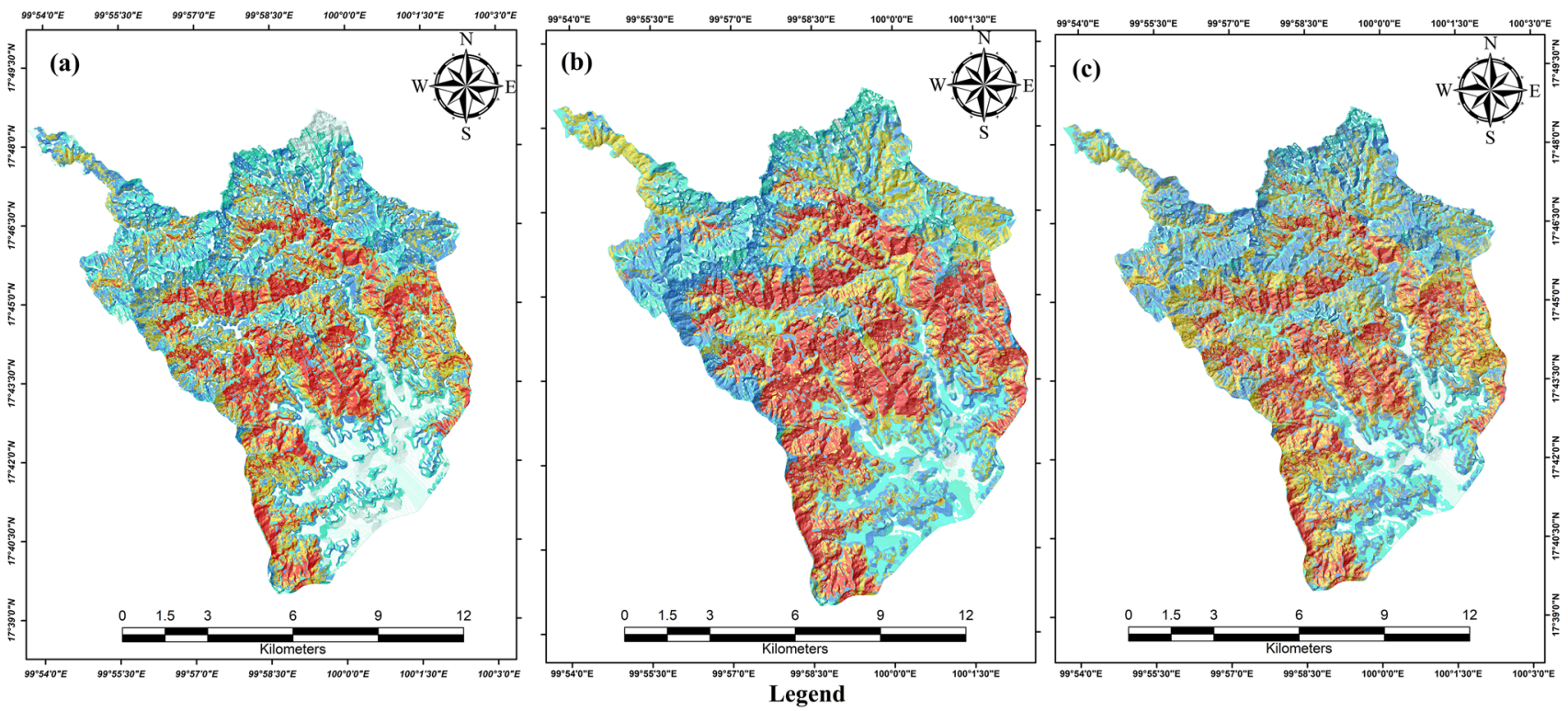

Landslide Susceptibility Zones

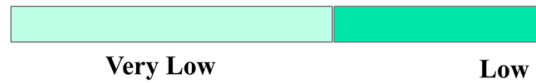

$$
\text { Low }
$$

Moderate

High

Very High

Fig. 6 Landslide susceptibility maps, a frequency ratio, $\mathbf{b}$ information value, $\mathbf{c}$ weight of evidence 
showed higher correlation with landslide occurrence as the $W^{\mathcal{C}}$ value was found high.

Slope degree shows high tendency toward occurrence of landslides, as it is clear from the results of weight of evidence that all slope classes have higher contrast value except $0^{\circ}-2.94^{\circ}$; as the slope gradient increases shear stress in soil, other materials also increase. As far as slope aspect is concerned, many landslides occurred on NE-, E-, SE-, S-, and SW-facing slopes with landslide area of 13.34, $16.84,11.91,12.06$, and $13.11 \%$, respectively. Results for land use/land cover map revealed that forest group has the highest $W^{\mathcal{C}}$ value of 0.71 with landslide area of $83.08 \%$. In case of distance from the streams, the classes 151-300 and 301-450 $\mathrm{m}$ have positive correlation with landslide with values of $W^{C} 0.20$ and 0.19 , respectively. Though, distance from the roads showed that the classes 601-900, 901-1200, and 1201-1500 meters has higher relationship with landslides, and area of landslide and contrast $(C)$ values are $22.21 \%, 0.53,15.54 \%, 0.42$, and $11.42,0.35$, respectively. From these observations, it is elucidated that road construction is the most significant factor in slope failure. In TWI, classes 0-4.91 and 4.92-7.22 have the contrast value of 0.17 and 0.10 , respectively, with landslide area of $32.74 \%$ and $43.78 \%$, respectively, but in SPI, classes of $0.67-1.89,1.90-3.23,3.24-5.63$, and 5.64-14.23 have the highest probability of landslide. Upwardly, concave and convex slope of curvature, plan, and profile curvature has positive relationship with landslides.

LSI map obtained from WOE model was classified into five susceptibility zones and is shown in Fig. 6c.

\subsection{Validation of the models}

All the three models were validated using prediction rate curves and success rate curves. Area under curve signifies the reliability of the model to predict the landslide events [67].

The validation landslides ( $30 \%$ of the total landslides) were used for predication curve, to predict the future landslides based on the present ones. The prediction rate curves were produced, and the area under curve (AUC) was obtained by plotting the landslides cumulative percentage area on $y$-axis against the cumulative percentage of landslide susceptibility area on $x$-axis. Success rate curve and prediction rate curve explain how well the model performed with the causative factor to predict landslides in future based on past landslides.

For success rate and predication rate curve calculation, landslide susceptibility index (LSI) values were divided into 100 equal classes which were sorted into descending order from very high to very low susceptibility classes. The validation and training landslide events were draped on it, and the area under curve was calculated using zonal statistics tool in ArcGIS.

Results were obtained for success rate curve by relating the training landslides with landslide susceptibility index (Fig. 8). The success of the models showed the area under curve (AUC) $74.60 \%, 75.04 \%$, and $72.54 \%$ for FR, IFV, and WOE, respectively.

Area under curve (AUC) value for the prediction rate curves of FR, IFV, and WOE was found $80.58 \%, 72.80 \%$, and $72.33 \%$, respectively (Fig. 7a). Thus, the AUC value for frequency ratio showed the highest accuracy in prediction rate curve, as compared to information value and weight of evidence. However, in success rate curve, almost all models showed the same accuracy. Frequency ratio and information value method showed almost same accuracy for success rate curve, but in prediction rate curve, the information value has better accuracy than frequency ratio for landslide susceptibility mapping in the study area. In this study, WOE model appears to be most reliable, since it corresponds close to the prediction of landslide potential in the study area.

\subsubsection{Landslide density}

An additional, landslide density test was also performed for consistency and quality of the landslide susceptibility models. Landslide density method was carried out on landslide susceptibility zones and validation landslide events. Landslide pixels were overlaid on susceptibility zones, and the density was estimated for landslide susceptibility zones. Landslide density values should increase with increase in susceptibility class [39]. In Fig. 7b-d, the bar graph shows the increasing trend of landslides with increment in susceptibility zones from very low to very high. Density of landslides slowly decreased from very high to very low landslide susceptibility zones. More than two-third of the landslides fall in high and very high susceptibility classes of all the models.

\subsubsection{Seed cell index area (SCAI)}

Seed cell area index (SCAI) used to test the accuracy of landslide susceptibility maps produced from FR, IFV, and WOE. SCAI was used on the classified landslide susceptibility maps and training landslides [68].

SCAI $=\frac{\text { Landslide susceptibility zone }(\%)}{\text { Landslides in each susceptibility zone (\%) }}$

It was assumed that the percentage of SCAI would be inversely proportional to the percentage of susceptibility zones [68]. Outcomes of SCAI obtained for all three approaches are shown in Table 1. 
(a)

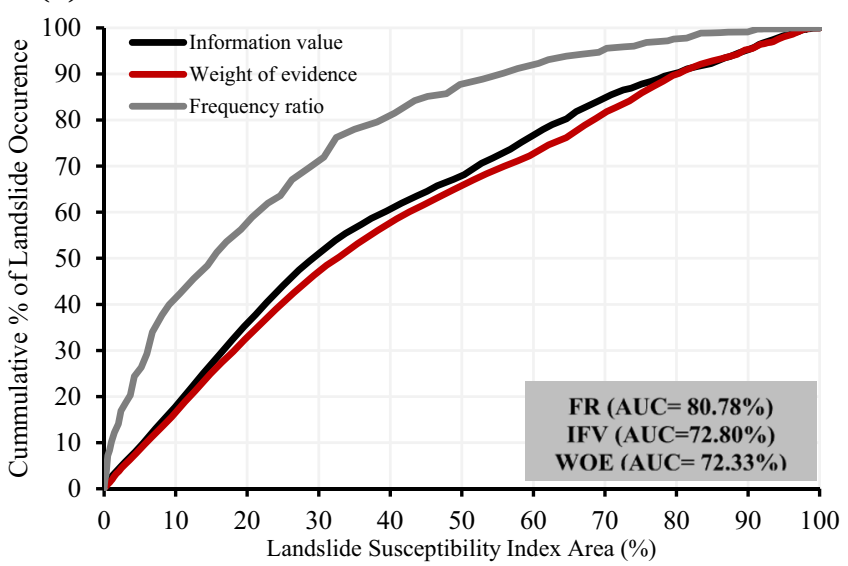

(c)

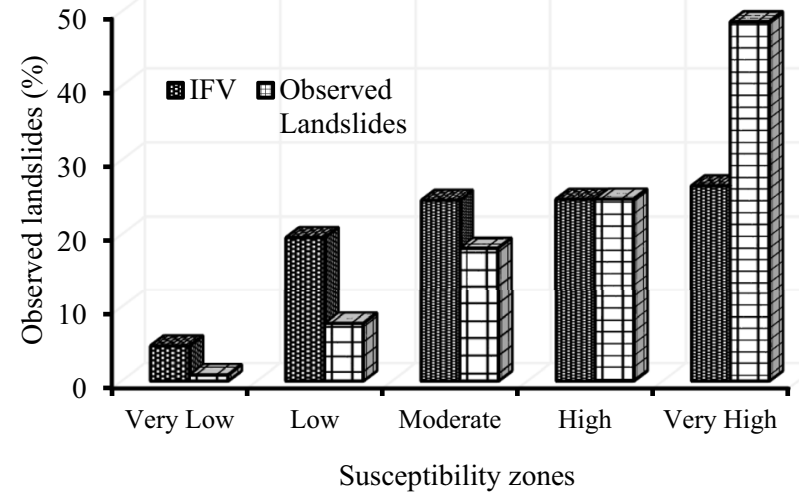

(b)

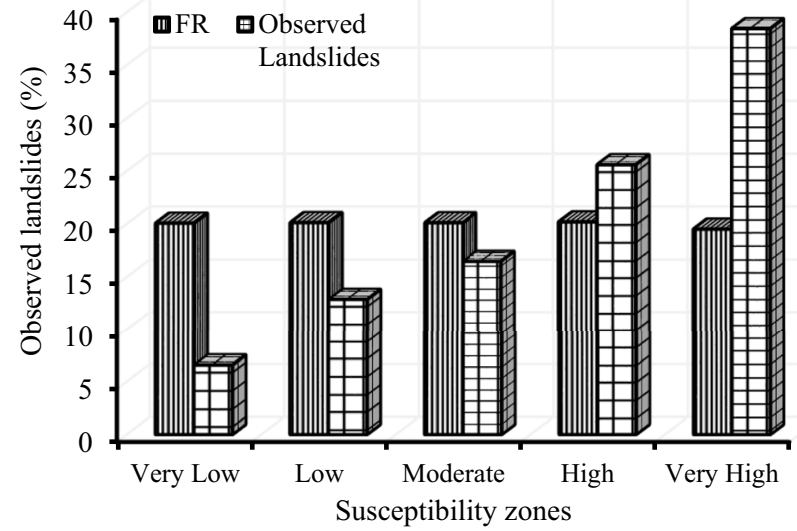

(d)

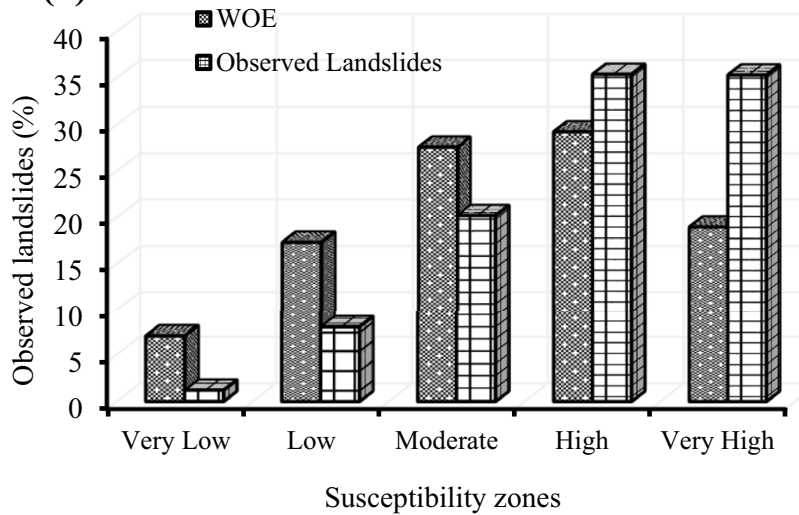

Fig. 7 a Predication rate curve, b observed landslides in FR susceptibility map, c observed landslides in IFV susceptibility map, d observed landslides in WOE susceptibility map

\subsection{Discussion}

Figure $6 \mathrm{a}-\mathrm{c}$ shows the landslide susceptibility maps generated using FR, IFV, and WOE models, respectively, and the relative significance of all influencing factors was evaluated with the occurrence of past landslides and is presented in Fig. 5. In this study, slope angle, elevation, land use/land cover, and roads have high FR, IFV, and $W^{c}$, and these factors are considered to be the most significant influencing factors for the occurrence of landslide in the study area which is in agreement with the results obtained by Ozdemir and Altural [21] comparing different models for landslide mapping.

In this study, forest land class from land cover factor has higher $W^{\mathcal{C}}, \mathrm{FR}$, and information value with $0.71,1.20$, and 0.078 , respectively, and lower in urban and agriculture land. The observation is in contrast to most of the studies because the forest areas may be more stable. Various studies explained that barren land is more exposed to landslide occurrence due to the direct exposure of climatic factors like, rain, snow, and sun rays $[19,69]$; though the case is
Table 1 Landslide distribution in landslide susceptibility zones using SCAI

\begin{tabular}{llccc}
\hline Methods & $\begin{array}{l}\text { Landslide } \\
\text { susceptibility } \\
\text { zones }\end{array}$ & \% of each zone & $\begin{array}{l}\text { \% of land- } \\
\text { slides in each } \\
\text { zone }\end{array}$ & SCAI \\
\hline FR & Very low & 20.06 & 6.56 & 2.23 \\
& Low & 20.12 & 12.88 & 1.13 \\
& Moderate & 20.11 & 16.48 & 1.36 \\
& High & 20.19 & 25.60 & 0.79 \\
& Very high & 19.50 & 38.45 & 0.59 \\
IFV & Very low & 4.72 & 0.80 & 3.13 \\
& Low & 19.56 & 7.77 & 1.87 \\
& Moderate & 24.54 & 18.12 & 1.27 \\
& High & 24.67 & 24.69 & 1.10 \\
& Very high & 26.49 & 48.59 & 0.57 \\
WOE & Very low & 6.99 & 1.19 & 2.22 \\
& Low & 17.30 & 7.977 & 1.66 \\
& Moderate & 27.55 & 20.16 & 1.25 \\
& High & 29.21 & 35.37 & 0.88 \\
& Very high & 18.92 & 35.29 & 0.61 \\
\hline
\end{tabular}


opposite here, same results have also found in other studies $[19,21,32,70]$. There could be many reasons behind it, but keeping the condition of the study area in mind, three reasons were found: (1) vegetation cover considered as a significant influencing factor in rainfall-induced landslides [71] and landslides in Thailand triggered due to intensive rainfall $[26,27],(2)$ the diverse root system of the trees at steep slopes, and (3) weight of the trees and unfavorable wind forces sometimes making the slopes susceptible [72]. The close relationship was found with distance from streams and roads with occurrence of landslides, distance from streams increases the occurrence of landslides decreases and fact found by Yalcin et al. [73] and Ozdemir and Altural [21]; though in roads, the maximum occurrence of landslides is found between 600 and $1500 \mathrm{~m}$, it is because of the natural landslides at higher slopes and elevation. Road cuts are mostly human-induced instability [41].

Similarly, streams can adversely disturb the slope stability by lateral and vertical erosion. Most of the landslides were found in the distance less than $450 \mathrm{~m}$ around the streams, and it can be presumed that occurrence of landslide is higher in the vicinity of streams. The slope angle between $2.95^{\circ}$ and $68.19^{\circ}$ has high tendency to landslide occurrence, and it means that the slope angle increases shear stress in soil as well as in other materials. Flat or gentle slope is less exposed to landslides hazard due to less shear stress associated with the material. The relationship between landslide and slope angle results of this study is in contrast to some previous studies (i.e., $[21,70]$ ) and has consistency with other studies which also elucidated that the occurrence of landslide increases with the increase in angle of slope gradient $[20,50,51]$. Elevation ranging from 177 to $462 \mathrm{~m}$ above mean sea level has high trend of landslides, while lower LS trend has found for the elevation ranging from 100-176 to 463-851 m. Occurrence of landslide probability increases with increase in altitude as landslides occur on high slopes. East facing slopes have the higher FR, $W^{C}$, and IFV value as compared to other directions and are more susceptible toward landslide (Fig. 5).

To validate the applied models for landslide, mapping success rate curve and prediction rate curve has been applied in this study using the training landslides. The results of success rate curve for FR, IFV, and WOE were $74.60 \%, 75.04 \%$, and $72.54 \%$, respectively (Fig. 8), while the results of prediction rate for FR, IFV, and WOE were $80.78 \%$, $72.80 \%$, and $72.33 \%$, respectively (Fig. $7 \mathrm{a}$ ). The accuracy of the applied landslide models was further analyzed using the SCAI technique, and a high number of landslides were found in the higher susceptible zones. Thus, the calculated and classified landslide susceptibility maps are in good agreement. Frequency ratio method showed the highest accuracy in prediction rate curve, but in success rate

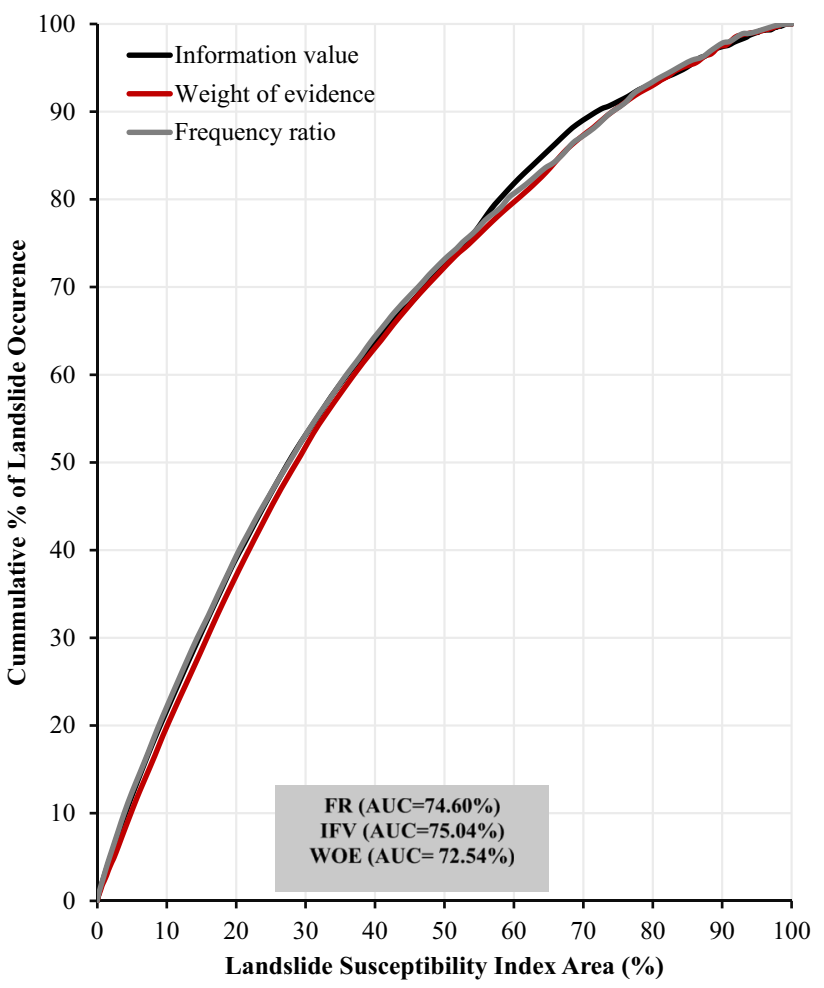

Fig. 8 Success rate curve for landslide susceptibility maps produced from IFV, FR, and WOE methods

curve, the area under curve for all the models was found the same (Fig. $7 b-d$ and Table 1).

The prediction accuracy obtained for frequency ratio in this study is comparable to previous studies $[1,17]$. The results of information value method of this study are slightly less than Sarkar et al's. [19] and Chen et al's. [67] study, while it is comparable to Achour et al. [18]. The prediction accuracy for weight of evidence obtained in this study is less than Mathew et al. [20], while it is comparable with the results obtained by Pourghasemi et al. [39]. It is clear from Figs. $7 a$ and 8 that the frequency ratio showed best accuracy in prediction $(80.78 \%)$ and in success rate curve $(74.60 \%)$ followed by IFV and WOE.

\section{Conclusion}

Studies in the past have applied these landslide susceptibility methods, i.e., FR, IR, and WOE, but there lacks an evidence of comparison for selection of most appropriate and accurate technique for the aforementioned study area. Therefore, this study not only utilizes these bivariate approaches but also provides a comparative analysis taking into consideration various influencing factors. Eventually, the results obtained were evaluated via AUC by taking landslide locations in consideration. The accuracy of the 
maps was $80.78 \%, 72.80$, and $72.33 \%$ for $\mathrm{FR}$, IFV, and WOE, respectively. Upon comparison and evaluation of prediction accuracy among the used quantitative approaches, it was revealed that FR method was highly reliable and accurate. FR method was able to predict almost $80 \%$ of the observed landslides as very high, high, and moderate landslide classes. Our results provided the basis to conclude WOE as a complicated method for applying to LS mapping. Several contributing factors for slope failure in Mae Phun include slope gradient, elevation, proximity to roads, and land use/land cover. Conclusively, we ascertain FR method to be most accurate, simple, easy, and intelligible method to be used for LS mapping.

Natural and sometimes human-induced disaster cannot be completely eliminated, but the aftermath can be minimized by proper planning and management. In the study area, there is no meteorological station, and it is suggested that meteorological stations should be installed because landslides in the study area are always associated with rainfall. So, the precipitation is necessary to be integrated with other influencing factors for more accurate results. Indeed, a real-time monitoring module would be more useful for the line department, end-users, and decision makers for a timely emergency response. Landslide susceptibility maps are useful for urban planners and engineers for better development. It can help land use planners with better decision making.

Acknowledgements This work was a part of a Master thesis completed at Naresuan University (Thailand). We are thankful to the department of natural resources and environment for providing the research facilities. We are also thankful to the Land Development Department (LDD) for providing land use data of the study area. Jaruntorn Boonyanuphap and Ghani Rahman reviewed the manuscript many times, and their scientific suggestion has improved the quality of the article. Further, we will extend our acknowledgment to Naresuan University international student scholarship for funding primary author's Master degree.

\section{Compliance with ethical standards}

Conflict of interest There is no conflict of interest.

\section{References}

1. Bourenane H, Guettouche MS, Bouhadad Y, Braham M (2016) Landslide hazard mapping in the Constantine city, Northeast Algeria using frequency ratio, weighting factor, logistic regression, weights of evidence, and analytical hierarchy process methods. Arab J Geosci 9(2):154. https://doi.org/10.1007/s1251 7-015-2222-8

2. Pradhan B, Mansor S, Pirasteh S, Buchroithner MF (2011) Landslide hazard and risk analyses at a landslide prone catchment area using statistical based geospatial model. Int J Remote Sens 32(14):4075-4087. https://doi.org/10.1080/01431 161.2010 .484433
3. Yalcin A (2008) GIS-based landslide susceptibility mapping using analytical hierarchy process and bivariate statistics in Ardesen (Turkey): comparisons of results and confirmations. CATENA 72(1):1-12. https://doi.org/10.1016/j.catena.2007.01.003

4. Pradhan B (2011) Manifestation of an advanced fuzzy logic model coupled with Geo-information techniques to landslide susceptibility mapping and their comparison with logistic regression modelling. Environ Ecol Stat 18(3):471-493. https:// doi.org/10.1007/s10651-010-0147-7

5. Sarkar S, Kanungo DP, Patra AK, Kumar P (2008) GIS based spatial data analysis for landslide susceptibility mapping. J Mt Sci 5(1):52-62. https://doi.org/10.1007/s11629-008-0052-9

6. Yilmaz I (2009) Landslide susceptibility mapping using frequency ratio, logistic regression, artificial neural networks and their comparison: a case study from Kat landslides (Tokat-Turkey). Comput Geosci 35(6):1125-1138. https://doi.org/10.1016/j. cageo.2008.08.007

7. Lee S, Pradhan B (2007) Landslide hazard mapping at Selangor, Malaysia using frequency ratio and logistic regression models. Landslides 4(1):33-41. https://doi.org/10.1007/s1034 6-006-0047-y

8. Rahman G, Rahman A, Samiullah, Collins A (2017) Geospatial analysis of landslide susceptibility and zonation in Shahpur valley, Eastern Hindu Kush using frequency ratio model. Proc Pak Acad Sci 54(3):149-163

9. Feizizadeh B, Blaschke T (2011) Landslide risk assessment based on GIS multi-criteria evaluation: a case study in Bostan-Abad County, Iran. J Earth Sci Eng 1(1):66-77

10. Rahman G, Rahman A, Ullah S, Miandad M, Collins AE (2019) Spatial analysis of landslide susceptibility using failure rate approach in the Hindu Kush region, Pakistan. J Earth Syst Sci 128(3):1-16

11. Rai PK, Mohan K, Kumra VK (2014) Landslide hazard and its mapping using remote sensing and GIS. J Sci Res 58:1-13

12. Sahoo S (2009) A semi quantitative landslide susceptibility assessment using logistic regression model and rock mass classification system. (Masters), ITC, Netherlands. Retrieved from https://www.itc.nl/library/papers_2009/msc/aes/sahoo.pdf

13. Corominas J, Van Westen C, Frattini P, Cascini L, Malet JP, Fotopoulou S, Pitilakis K (2014) Recommendations for the quantitative analysis of landslide risk. Bull Eng Geol Environ 73:209-263

14. Boroumandi M, Khamehchiyan M, Nikoudel MR (2015) Using of analytic hierarchy process for landslide hazard zonation in Zanjan Province, Iran. In: Lollino G, Giordan D, Crosta GB, Corominas J, Azzam R, Wasowski J, Sciarra N (eds) Engineering geology for society and territory: landslide processes, vol 2. Springer, Cham, pp 951-955

15. Intarawichian N, Dasananda S (2010) Analytical hierarchy process for landslide susceptibility mapping in lower Mae Chaem watershed, Northern Thailand. Suranaree J Sci Technol 17(3):277-292

16. Moazzam MFU, Vansarochana A, Boonyanuphap J, Choosumrong $S$ (2017) Landslide assessment using GIS-based frequency ratio method: a case study of Mae-Phun Sub-District, Laplae District, Uttaradit Province, Thailand. Paper presented at the 38th Asian conference on remote sensing, Delhi, India

17. Park S, Choi C, Kim B, Kim J (2013) Landslide susceptibility mapping using frequency ratio, analytic hierarchy process, logistic regression, and artificial neural network methods at the Inje area, Korea. Environ Earth Sci 68(5):1443-1464. https://doi. org/10.1007/s12665-012-1842-5

18. Achour Y, Boumezbeur A, Hadji R, Chouabbi A, Cavaleiro V, Bendaoud EA (2017) Landslide susceptibility mapping using analytic hierarchy process and information value methods along a highway road section in Constantine, Algeria. Arab J Geosci 10(8):194. https://doi.org/10.1007/s12517-017-2980-6 
19. Sarkar S, Roy A, Martha TR (2013) Landslide susceptibility assessment using information value method in parts of the Darjeeling Himalayas. J Geol Soc India. https://doi.org/10.1007/s1259 4-013-0162-z

20. Mathew J, Jha VK, Rawat GS (2007) Weights of evidence modelling for landslide hazard zonation mapping in part of Bhagirathi valley, Uttarakhand. Curr Sci 92:628-638

21. Ozdemir A, Altural T (2013) A comparative study of frequency ratio, weights of evidence and logistic regression methods for landslide susceptibility mapping: Sultan Mountains, SW Turkey. J Asian Earth Sci 64:180-197. https://doi.org/10.1016/j.jseae s.2012.12.014

22. Amade N, Painho M, Oliveira T (2018) Geographic information technology usage in developing countries-a case study in Mozambique. Geo-spatial Inf Sci 21(4):331-345

23. Greco SE (2018) Seven possible states of geospatial data with respect to map projection and definition: a novel pedagogical device for GIS education. Geo-spatial Inf Sci 21(4):288-293

24. Sharma M, Kumar R (2008) GIS based landslide hazard zonation: a case study from the Parwanoo area, lesser and outer Himalaya, H.P., India. Bull Eng Geol Environ. https://doi.org/10.1007/s1006 4-007-0113-2

25. Anucharn T (2015) Optimal landslide susceptibility and risk analysis at Khao Phanom Bencha, Krabi Province, Thailand. Ph.D., Suranaree University of Technology

26. Intarawichian N, Dasananda S (2011) Frequency ratio model based landslide susceptibility mapping in lower Mae Chaem watershed, Northern Thailand. Environ Earth Sci 64(8):22712285. https://doi.org/10.1007/s12665-011-1055-3

27. Oh H-J, Lee S, Chotikasathien W, Kim CH, Kwon JH (2008) Predictive landslide susceptibility mapping using spatial information in the Pechabun area of Thailand. Environ Geol 57(3):641. https ://doi.org/10.1007/s00254-008-1342-9

28. Boonyanuphap J (2013) Cost-benefit analysis of vetiver systembased rehabilitation measures for landslide-damaged mountainous agricultural lands in the lower Northern Thailand. Nat Hazards 69(1):599-629. https://doi.org/10.1007/s1106 9-013-0730-y

29. Tatong $T$ (2013) The best practices for landslide monitoring and warning in Maephun Subdistrict, Lublae District, Uttaradit Province

30. Ono K, Kazama S, Ekkawatpanit C (2014) Assessment of rainfallinduced shallow landslides in Phetchabun and Krabi provinces, Thailand. Nat Hazards 74(3):2089-2107. https://doi.org/10.1007/ s11069-014-1292-3

31. Phattaraporn S, Anusorn R, Thitawadee S (2017) Analyzing the effects of land use changes for landslide susceptibility assessment: a case study of Lablae District, Uttaradit Province, Thailand. Paper presented at the 38th Asian conference on remote sensing, New Delhi, India

32. Teerarungsigul S, Torizin J, Fuchs M, Kuhn F, Chonglakmani C (2016) An integrative approach for regional landslide susceptibility assessment using weight of evidence method: a case study of Yom River Basin, Phrae Province, Northern Thailand. Landslides 13(5):1151-1165. https://doi.org/10.1007/s1034 6-015-0659-1

33. Thammapala P, Weng J (2015) Using geo-informatics for landslide risk map in northern Thailand. Paper presented at the international conference on intelligent earth observing and applications

34. Usamah M, Arambepola N (2013) Lessons learned from the 2006 flashfloods and landslide in Uttaradit and Sukhothai Provinces: implication for effective landslide disaster risk management in Thailand landslide science and practice. Springer, pp 693-699

35. Nachaiboon U, Phewnil O, Duangmal K, Chanwong N, Rollap P, Wichittrakarn P, Nimpee C (2014) Effect of landform pattern on soil particles in landslide crisis area of Mae Phun and Mae Phrong Watershed, Uttaradit Province, Northern of Thailand

36. van Westen CJ, Rengers N, Soeters R (2003) Use of geomorphological information in indirect landslide susceptibility assessment. Nat Hazards 30(3):399-419. https://doi.org/10.1023/ B:NHAZ.0000007097.42735.9e

37. Ayalew L, Yamagishi H, Ugawa N (2004) Landslide susceptibility mapping using GIS-based weighted linear combination, the case in Tsugawa area of Agano River, Niigata Prefecture, Japan. Landslides 1(1):73-81. https://doi.org/10.1007/s1034 6-003-0006-9

38. Guzzetti F, Mondini AC, Cardinali M, Fiorucci F, Santangelo M, Chang K-T (2012) Landslide inventory maps: new tools for an old problem. Earth-Sci Rev 112(1-2):42-66. https://doi. org/10.1016/j.earscirev.2012.02.001

39. Pourghasemi HR, Pradhan B, Gokceoglu C, Mohammadi M, Moradi HR (2013) Application of weights-of-evidence and certainty factor models and their comparison in landslide susceptibility mapping at Haraz watershed, Iran. Arab J Geosci 6(7):2351-2365. https://doi.org/10.1007/s12517-012-0532-7

40. Guzzetti F, Carrara A, Cardinali M, Reichenbach P (1999) Landslide hazard evaluation: a review of current techniques and their application in a multi-scale study, Central Italy. Geomorphology 31(1):181-216

41. Ayalew L, Yamagishi $H$, Marui $H$, Kanno T (2005) Landslides in Sado Island of Japan: Part II. GIS-based susceptibility mapping with comparisons of results from two methods and verifications. Eng Geol 81(4):432-445. https://doi.org/10.1016/j.engge o.2005.08.004

42. Magliulo P, Di Lisio A, Russo F, Zelano A (2008) Geomorphology and landslide susceptibility assessment using GIS and bivariate statistics: a case study in southern Italy. Nat Hazards 47(3):411435. https://doi.org/10.1007/s11069-008-9230-x

43. Akgun A, Türk N (2010) Landslide susceptibility mapping for Ayvalik (Western Turkey) and its vicinity by multicriteria decision analysis. Environ Earth Sci 61(3):595-611. https://doi. org/10.1007/s12665-009-0373-1

44. Balamurugan G, Ramesh V, Touthang M (2016) Landslide susceptibility zonation mapping using frequency ratio and fuzzy gamma operator models in part of NH-39, Manipur, India. Nat Hazards 84(1):465-488. https://doi.org/10.1007/s1106 9-016-2434-6

45. Çevik E, Topal T (2003) GIS-based landslide susceptibility mapping for a problematic segment of the natural gas pipeline, Hendek (Turkey). Environ Geol 44(8):949-962. https://doi. org/10.1007/s00254-003-0838-6

46. Jaiswal P, van Westen CJ, Jetten V (2010) Quantitative landslide hazard assessment along a transportation corridor in southern India. Eng Geol 116(3):236-250. https://doi.org/10.1016/j.engge o.2010.09.005

47. Deniz T, Paletto A (2018) Effects of bioenergy production on environmental sustainability: a preliminary study based on expert opinions in Italy and Turkey. J For Res 29(6):1611-1626

48. Dai FC, Lee CF, Li J, Xu ZW (2001) Assessment of landslide susceptibility on the natural terrain of Lantau Island, Hong Kong. Environ Geol 40(3):381-391. https://doi.org/10.1007/s0025 40000163

49. Saha AK, Gupta RP, Arora MK (2002) GIS-based Landslide Hazard Zonation in the Bhagirathi (Ganga) Valley, Himalayas. Int J Remote Sens 23(2):357-369. https://doi.org/10.1080/01431 160010014260

50. Dahal RK, Hasegawa S, Nonomura A, Yamanaka M, Dhakal S, Paudyal P (2008) Predictive modelling of rainfall-induced landslide hazard in the Lesser Himalaya of Nepal based on weightsof-evidence. Geomorphology 102(3-4):496-510. https://doi. org/10.1016/j.geomorph.2008.05.041 
51. Dahal RK, Hasegawa S, Nonomura A, Yamanaka M, Masuda T, Nishino K (2008) GIS-based weights-of-evidence modelling of rainfall-induced landslides in small catchments for landslide susceptibility mapping. Environ Geol 54(2):311-324. https:// doi.org/10.1007/s00254-007-0818-3

52. Demir G, Aytekin M, Akgün A, İkizler SB, Tatar O (2013) A comparison of landslide susceptibility mapping of the eastern part of the North Anatolian Fault Zone (Turkey) by likelihood-frequency ratio and analytic hierarchy process methods. Nat Hazards 65(3):1481-1506. https://doi.org/10.1007/s11069-012-0418-8

53. Kavzoglu T, Sahin EK, Colkesen I (2014) Landslide susceptibility mapping using GIS-based multi-criteria decision analysis, support vector machines, and logistic regression. Landslides 11(3):425-439. https://doi.org/10.1007/s10346-013-0391-7

54. Kayastha P, Dhital MR, De Smedt F (2013) Application of the analytical hierarchy process (AHP) for landslide susceptibility mapping: a case study from the Tinau watershed, west Nepal. Comput Geosci 52:398-408. https://doi.org/10.1016/j.cageo .2012.11.003

55. Lee S, Ryu JH, Min K, Won JS (2003) Landslide susceptibility analysis using GIS and artificial neural network. Earth Surf Process Landf 28(12):1361-1376. https://doi.org/10.1002/esp.593

56. Pradhan B (2010) Application of an advanced fuzzy logic model for landslide susceptibility analysis. Int J Comput Intell Syst. https://doi.org/10.1080/18756891.2010.9727707

57. Moore ID, Grayson RB, Ladson AR (1991) Digital terrain modelling: a review of hydrological, geomorphological, and biological applications. Hydrol Process 5(1):3-30. https://doi.org/10.1002/ hyp. 3360050103

58. Kanwal S, Atif S, Shafiq M (2016) GIS based landslide susceptibility mapping of northern areas of Pakistan, a case study of Shigar and Shyok Basins. Geomat Nat Hazards Risk. https://doi. org/10.1080/19475705.2016.1220023

59. Lee S, Min K (2001) Statistical analysis of landslide susceptibility at Yongin, Korea. Environ Geol 40(9):1095-1113. https://doi. org/10.1007/s002540100310

60. Oh H-J, Kim Y-S, Choi J-K, Park E, Lee S (2011) GIS mapping of regional probabilistic groundwater potential in the area of Pohang City, Korea. J Hydrol 399(3):158-172. https://doi. org/10.1016/j.jhydrol.2010.12.027

61. Yin K, Yan T (1988) Statistical prediction model for slope instability of metamorphosed rocks. Paper presented at the Proceedings of the 5th international symposium on landslides

62. van Westen CJ (1993) Application of geographic information systems to landslide hazard zonation. International Institute for Geo-Information Science and Earth Observation, Enschede

63. Vansarochana A, Tripathi NK, Clemente R (2009) Investigating mudslide phenomenon in Mae Cham Basin, Thailand. Paper presented at the geoinformation technology for natural disaster management and rehabilitation, Bangkok, Thailand

64. Zêzere JL (2002) Landslide susceptibility assessment considering landslide typology. A case study in the area north of Lisbon (Portugal). Nat Hazards Earth Syst Sci 2(1/2):73-82

65. Saha AK, Gupta RP, Sarkar I, Arora MK, Csaplovics E (2005) An approach for GIS-based statistical landslide susceptibility zonation — with a case study in the Himalayas. Landslides 2(1):61-69. https://doi.org/10.1007/s10346-004-0039-8

66. Bonham-Carter GF (1989) Weights of evidence modeling: a new approach to mapping mineral potential. Stat Appl Earth Sci 98:171-183

67. Chen T, Niu RQ, Jia XP (2016) A comparison of information value and logistic regression models in landslide susceptibility mapping by using GIS. Environ Earth Sci 75(10):867. https://doi. org/10.1007/s12665-016-5317-y

68. Süzen ML, Doyuran V (2004) A comparison of the GIS based landslide susceptibility assessment methods: multivariate versus bivariate. Environ Geol 45(5):665-679. https://doi. org/10.1007/s00254-003-0917-8

69. Bacha AS, Shafique M, van der Werff H (2018) Landslide inventory and susceptibility modelling using geospatial tools, in Hunza-Nagar valley, northern Pakistan. J Mt Sci 2018:1-17

70. Mohammady M, Pourghasemi HR, Pradhan B (2012) Landslide susceptibility mapping at Golestan Province, Iran: a comparison between frequency ratio, Dempster-Shafer, and weightsof-evidence models. J Asian Earth Sci 61:221-236. https://doi. org/10.1016/j.jseaes.2012.10.005

71. Beguería S (2006) Changes in land cover and shallow landslide activity: a case study in the Spanish Pyrenees. Geomorphology 74(1):196-206. https://doi.org/10.1016/j.geomorph.2005.07.018

72. Green-way DR (1987) Vegetation and slope stability. In: Anderson MG, Richards KS (eds) Slope stability. Wiley, Chichester, pp 187-230

73. Yalcin A, Reis S, Aydinoglu AC, Yomralioglu T (2011) A GIS-based comparative study of frequency ratio, analytical hierarchy process, bivariate statistics and logistics regression methods for landslide susceptibility mapping in Trabzon, NE Turkey. CATENA 85(3):274-287. https://doi.org/10.1016/j.catena.2011.01.014

Publisher's Note Springer Nature remains neutral with regard to jurisdictional claims in published maps and institutional affiliations. 